\title{
MAISTO PAPILDO MACA BOOSTER POVEIKIS SPORTININKŲ ORGANIZMO ADAPTACIJAI PRIE FIZINIŲ KRŪVIŲ
}

\author{
Kazys Milašius, Rūta Dadelienė, Marija Pečiukonienė, Juozas Skernevičius
} Vilniaus pedagoginis universitetas, Vilnius, Lietuva

\begin{abstract}
Kazys Milašius. Biomedicinos mokslų habilituotas daktaras profesorius. Vilniaus pedagoginio universiteto Sporto metodikos katedros vedèjas. Sporto mokslo instituto direktorius. Mokslinių tyrimų kryptis — organizmo adaptacija prie fizinių krūvių, sportininkų vartojamų maisto papildų veiksmingumo tyrimai, sporto treniruotès valdymas.
\end{abstract}

\section{SANTRAUKA}

Sportininkai vis labiau vartoja Vokietijos firmoje „Almondi“ gaminama maisto papilda Maca booster. Pagrindinis šio maisto papildo komponentas yra natūralus augalas peruvinè pipirinè (Lepidium meyenii) (Maca), auganti Andu kalnuose (4000-4500 m virš jūros lygio). Nors šis augalas vartojamas kaip tonizuojamoji medžiaga, mažinanti nuovargi, didinanti potencija ir vaisinguma, gerinanti medžiagu apykaita, normalizuojanti vegetacinès nervu sistemos funkcija, gerinanti organizmo imunine bükle, stiprinanti širdies ir kraujagysliu sistema, didinanti ištvermę esant deguonies trūkumui ir pan., tačiau moksliniais tyrimais tai dar nepakankamai irodyta. Taigi tyrimo tikslas - nustatyti, kaip maisto papildas Maca booster veikia sportininku fizini darbinguma, morfologinę ir biocheminę kraujo sudèti.

Buvo tiriama 16 sportininku, kuriu amžius - 20-22 metai. Tiriamieji 20 dienu vartojo po 5 maisto papildo Maca booster kapsules per diena: po 2 kapsules ryte, 1 - per pietus ir 2 -vakare. Vienoje kapsuleje yra $800 \mathrm{mg}$ sausu peruvinès pipirinès šaknu milteliu. Sportininkai buvo tiriami prieš pradedant jiems vartoti maisto papilda, praejjus 10 ir 20 dienu nиo vartojimo pradžios ir praejus 20 dienu po šio papildo vartojimo pabaigos.

Nustatytas vienkartinis raumenu susitraukimo galingumas (VRSG), anaerobinis alaktatinis raumenu galingumas $(A A R G)$, raumenu galingumas atliekant $10 \mathrm{~s}$ trukmès krüvi maksimaliomis pastangomis, anaerobinis glikolitinis pajégumas $(A G P)$. Aerobiniam pajegumui vertinti taikème $P W C_{170}$ testa. Krauja morfologiniams, biocheminiams ir hormonu tyrimams atlikti èméme iš venos.

Per eksperimentini laikotarpi santykinis VRSG padidëjo nuo 25,9 iki 27,4 W/ $\mathrm{kg}(p<0,05)$. Santykinis AARG rodiklis per tiriamaji laikotarpi padidejo nuo 16,3 $\pm 0,3$ iki $17,3 \pm 0,4 \mathrm{~W} / \mathrm{kg}(\mathrm{p}<0,05) .10 \mathrm{~s}$ trukmés krūvio maksimaliomis pastangomis darbo galingumo reikšme didèjo nuo 18,3 $\pm 0,5 \mathrm{iki} 20,3 \pm 0,5 \mathrm{~W} / \mathrm{kg}(\mathrm{p}<0,05)$. Anaerobinis glikolitinis pajegumas $(A G P)$ didejo nиo 494,8 $\pm 12,3 \mathrm{~W}$ iki 530,1 $\pm 11,0 \mathrm{~W}(\mathrm{p}<0,05)$ o santykinis - nuo 6,4 $\pm 0,1 \mathrm{iki}$

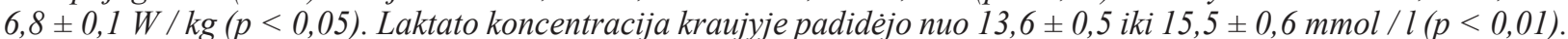
Nustateme, kad 20 dienu vartojant maisto papildq Maca booster $P W C_{170}$ padidejo vidutiniškai $8,8 W(p>0,05)$.

Nekintant leukocitu kiekiui sportininku kraujyje, po 10 dienu Maca booster vartojimo padidejo limfocitu procentas nиo 34,8 iki 39,9\% ir skaičius - nио 2,4 $\pm 0,2$ iki $2,5 \pm 0,1610^{9} / l(p<0,05)$.

Tiriamuju kraujyje kreatinkinazès, kreatinino, šlapimo rūgšties ir šlapalo koncentracijos poslinkiai per eksperimentinj laikotarpi parode, kad Maca booster vartojimas gali lemti sportininku organizmo fiziniu galiu didèjimo galimybes.

Vartojant Maca booster, jau po 10 dienu buvo pastebètas testosterono koncentracijos padidejimas nиo 28,6 1 1,94 iki 31,95 $\pm 2,15 \mu \mathrm{mol} / \mathrm{l}(\mathrm{p}>0,05)$.

Po 20 dienu šio papildo vartojimo testosterono kiekis statistiškai reikšmingai sumažejo iki 26,06 1,60 $\mu$ mol / l.

Taigi tyrimas parodè, kad maisto papildas Maca booster teigiamai veikia sportininku fizini pajéguma ivairiose energijos gamybos zonose ir ju organizmo imunine būsenq.

Raktažodžiai: maisto papildai, fizinis išsivystymas, fizinis galingumas, funkcinis pajègumas.

\section{IVADAS}

$\mathrm{P}$ astaruoju metu tarp sportininkų didesni pripažinimą igyja maisto papildai, gaminami iš natūralaus augalo peruvinès pipirinès (Maca) (Lepidium meyenii), augančios Andų kalnuose (4000- $4500 \mathrm{~m}$ virš jūros lygio). Tai saugus, ekologiškai švarus produktas, Lotynų Amerikos šaliu gyventojų vartojamas jẻgoms atgauti, kaip svei- katinimo priemonè (Hernandez, Leon, 1994; Shugarman, 2002; Zuniga, Flores, 2003). Veikliosios medžiagos yra susikaupusios peruvinès pipirinès augalo šaknyse, iš kurių gaminami ivairios formos preparatai: milteliai, tabletès, kapsulès. Vienas iš tokiu preparatu yra Vokietijos firmos „Almondi“ gaminamas maisto papildas Maca booster. Nors šis 
maisto papildas sportininkų vis plačiau vartojamas kaip tonizuojamasis, mažinantis nuovargi, didinantis potenciją ir vaisingumą, gerinantis medžiagu apykaita, normalizuojantis vegetacinès nervų sistemos funkcija, gerinantis organizmo imuninę būklę, stiprinantis širdies ir kraujagysliu sistemą, didinantis ištvermę esant deguonies trūkumui ir pan. (Gonzales et al., 2002; Brinckmann, Smith, 2004), tačiau moksliniais tyrimais tai dar nepakankamai irodyta. Išsiaiškinus konkretų šio preparato poveiki sportininkų organizmui, bus galima tikslingiau ji taikyti rengiant didelio meistriškumo sportininkus, kurie siekia geriausių rezultatų Europos, pasaulio čempionatuose ir olimpinèse žaidynèse.

Tyrimo tikslas - nustatyti, kaip maisto papildas Maca booster veikia sportininkų fizini darbinguma, funkcini pajègumą, morfologinę ir biocheminę kraujo sudèti.

\section{TYRIMO ORGANIZAVIMAS IR METODAI}

Buvo tiriama 16 sportininkų, kurių amžius 20-22 metai. Jų kūno masè - 77,9 $\pm 8,1 \mathrm{~kg}$, kūno masès indeksas $-23,9 \pm 2,6$. Tiriamieji 20 dienų vartojo po 5 maisto papildo Maca booster kapsules per dieną: 2 kapsules ryte, 1 - per pietus ir 2 - vakare. Vienoje kapsuleje yra $800 \mathrm{mg}$ sausu peruvinès pipirinès (Maca) (Lepidium meyenii) šaknų miltelių. Sportininkai buvo tiriami prieš pradedant vartoti maisto papildą (I tyrimas), praejjus 10 (II tyrimas), 20 dienų (III tyrimas) nuo vartojimo pradžios ir praejjus dar 20 dienų po šio papildo vartojimo (IV tyrimas).

Nustatant fizini išsivystymą buvo taikoma standartinè metodika (Norton et al., 1996). Apie raumenu galingumą ivairiose energijos gamybos zonose sprendėme nustatydami vienkartini raumenų susitraukimo galingumą (VRSG) (Bosco et al., 1982). Anaerobini alaktatini raumenu galingumą (AARG) vertinome R. Margaria, P. Aghemo, E. Rovelli (1966) ir $10 \mathrm{~s}$ trukmès krūvio maksimaliomis pastangomis testais. Anaeroniniam glikolitiniam pajègumui (AGP), kai raumenų mechaninès energijos gamyboje vyrauja glikolitinès reakcijos, vertinti taikème $60 \mathrm{~s}$ trukmès krūvị maksimaliomis pastangomis, atliekamą veloergometru „Monark-894E“ (Szögy, Cherebetin, 1979). Apskaičiavome absoliučias ir santykines $1 \mathrm{~kg}$ kūno masès tenkančio darbo galingumo reikšmes. Aerobiniam pajëgumui vertinti taikème plačiai paplitusi $\mathrm{PWC}_{170}$ testą (Eurofitas, 1993). Laktato koncentracija nustatyta po $3 \mathrm{~min}$ atlikus $60 \mathrm{~s}$ trukmès krūvị maksimaliomis pastangomis, naudojant analizatoriu „Lactate Pro“ (Japonija). Kraujo morfologiniai tyrimai atlikti hematologiniu analizatoriumi „Micros-60“, biocheminiai tyrimai - ekspresanalizatoriumi „Reflatron-IV“.

Testosterono (TTE) ir augimo hormono (STH) koncentracija buvo nustatoma automatiniais imunologiniais analizatoriais „Immulite“ ir „Immulite 2000“(Siemens).

Tyrimu duomenys apdoroti matematinès statistikos metodais, apskaičiuojant aritmetini vidurki () ir standartini nuokrypi (S). Skirtumų patikimumui vertinti taikytas dispersinès analizès metodas. Fcrit patikimumas $>4,17$.

\section{REZULTATAI}

Per eksperimentini laikotarpi santykinis VRSG padidejo nuo $25,9 \pm 4,7$ iki $27,4 \pm 5,2 \mathrm{~W} / \mathrm{kg}$ $(\mathrm{p}<0,05)(1 \mathrm{pav}$.$) . Santykinis AARG rodiklis per$ tiriamaji laikotarpi padidejo nuo $16,3 \pm 1,1$ iki $17,3 \pm 1,7 \mathrm{~W} / \mathrm{kg}(\mathrm{p}<0,05)$ (2 pav.). $10 \mathrm{~s}$ trukmès

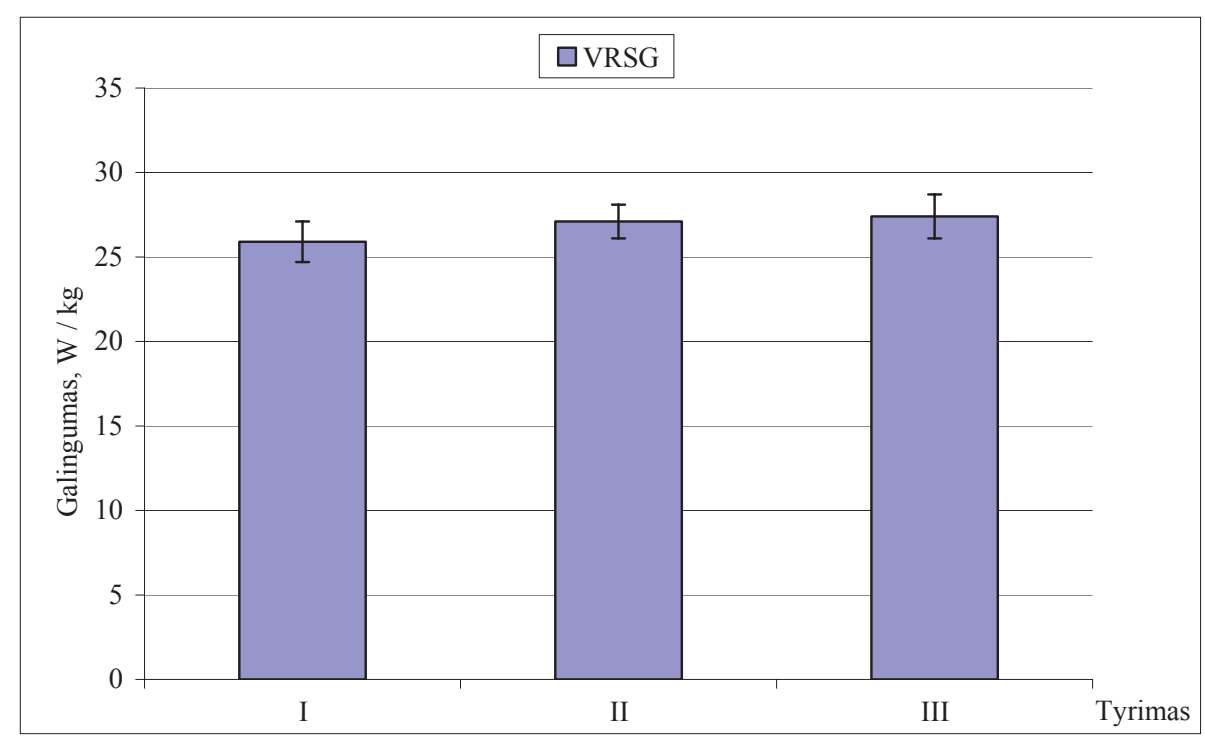

1 pav. Maisto papildo Maca booster poveikis sportininkų vienkartinio raumenų susitraukimo galingumui 
2 pav. Maisto papildo Maca booster poveikis sportininkų anaerobiniam alaktatiniam raumenų galingumui

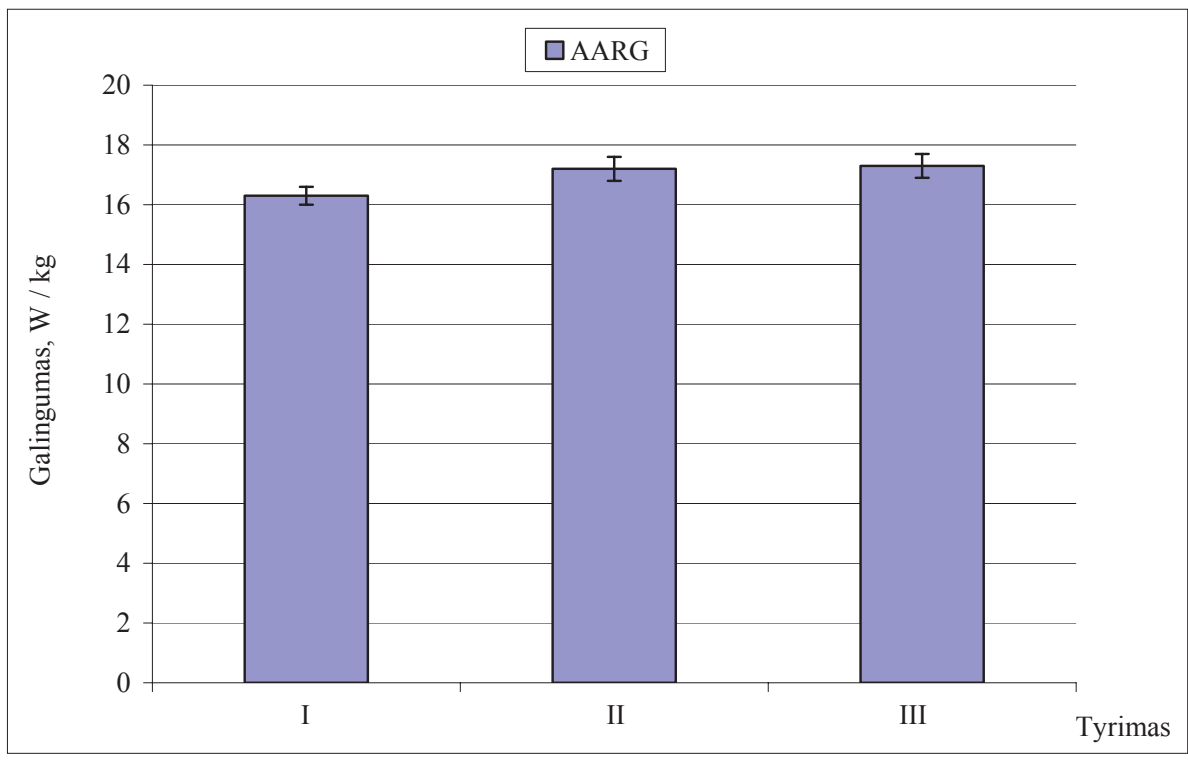

3 pav. Maisto papildo Maca booster poveikis sportininkų galingumui atliekant $10 \mathrm{~s}$ trukmès testą

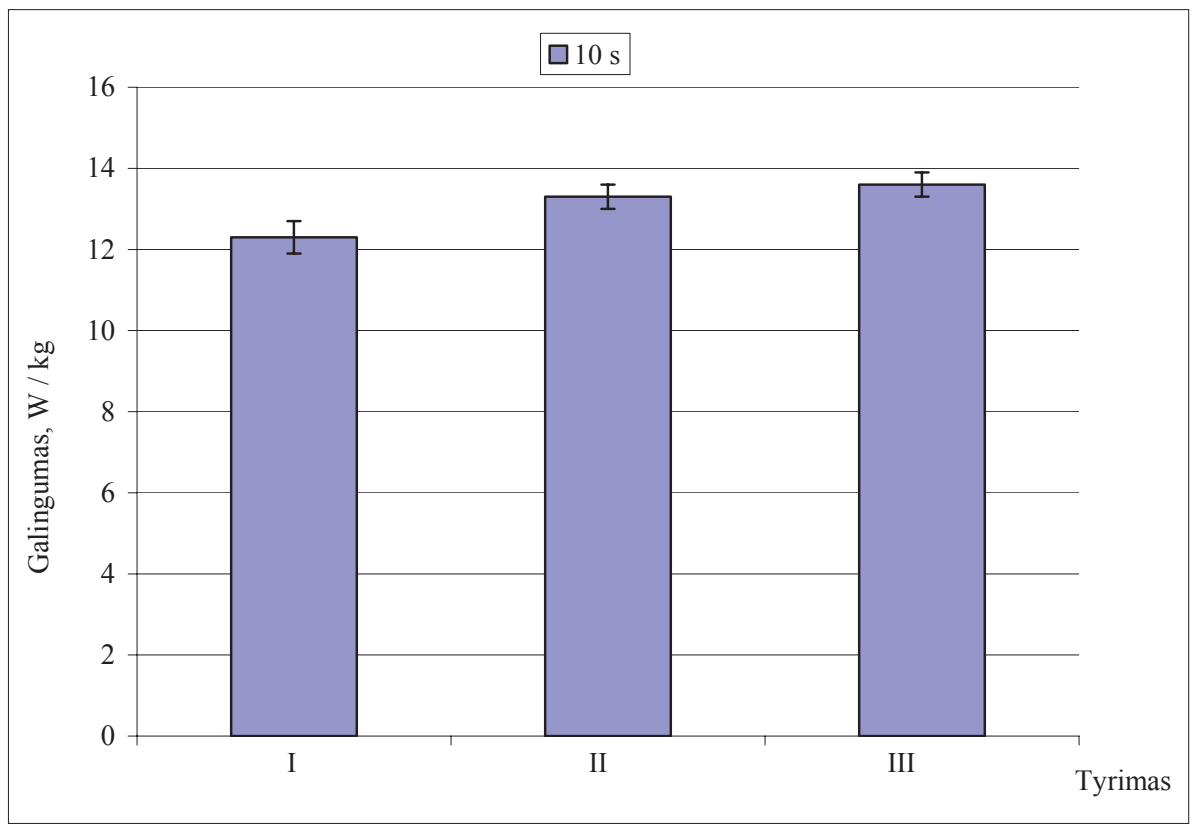

krūvio maksimaliomis pastangomis metu darbo galingumo vidurkis padidejo nuo $12,3 \pm 1,4 \mathrm{iki}$ $13,6 \pm 1,2 \mathrm{~W} / \mathrm{kg},(\mathrm{p}<0,01)$ (3 pav.). Anaerobinis glikolitinis pajègumas padidejo nuo $6,4 \pm 0,5$ iki $6,8 \pm 0,5 \mathrm{~W} / \mathrm{kg}(\mathrm{p}<0,05)$ (4 pav.). Laktato koncentracija kraujyje po $60 \mathrm{~s}$ trukmès fizinio krūvio padidejo nuo $13,6 \pm 0,5$ iki $15,5 \pm 0,6 \mathrm{mmol} / 1$ ( $\mathrm{p}<0,01)$. Nustatyta, kad 20 dienų vartojant maisto papildą Maca booster $\mathrm{PWC}_{170}$ padidejo vidutiniškai $8,8 \mathrm{~W}(\mathrm{p}>0,05)(5 \mathrm{pav}$.).

Nekintant leukocitu kiekiui sportininku kraujyje, po 10 dienų trukusio Maca booster vartojimo padidejo limfocitu procentas nuo 34,8 iki 39,9\% $(\mathrm{p}<0,05)$ (1 lent.). Statistiškai reikšmingai sumažèjęs eritrocitų nusėdimo greitis ir limfocitų procentinio rodiklio padidejimas po 10 dienu maisto papildo vartojimo parode, kad Maca booster pa- skatino limfocitų suaktyvèjimą, tačiau dar po 10 dienos limfocitu procento leukocituose rodikliai vèl grižo i pradini lygi ir tokie buvo praejus dar 20 dienų po maisto papildo vartojimo.

Tiriamuju kraujyje kreatinkinazès, kreatinino, šlapimo rūgšties ir šlapalo koncentracijos poslinkiai per eksperimentini laikotarpi parodè, kad Maca booster vartojimas gali lemti sportininkų organizmo fizinių galių didejjimo galimybes (2 lent.).

Vartojant Maca booster jau po 10 dienų buvo pastebėtas testosterono koncentracijos padidèjimas nuo $28,6 \pm 1,94$ iki $31,95 \pm 2,15 \mu \mathrm{mol} / 1$ $(\mathrm{p}>0,05)$. Dar po 10 dienų šio papildo vartojimo testosterono kiekis statistiškai reikšmingai sumažèjo iki 26,06 $\pm 1,60 \mu \mathrm{mol} / 1(\mathrm{~F}=4,839$; $\mathrm{p}<0,05)$. 


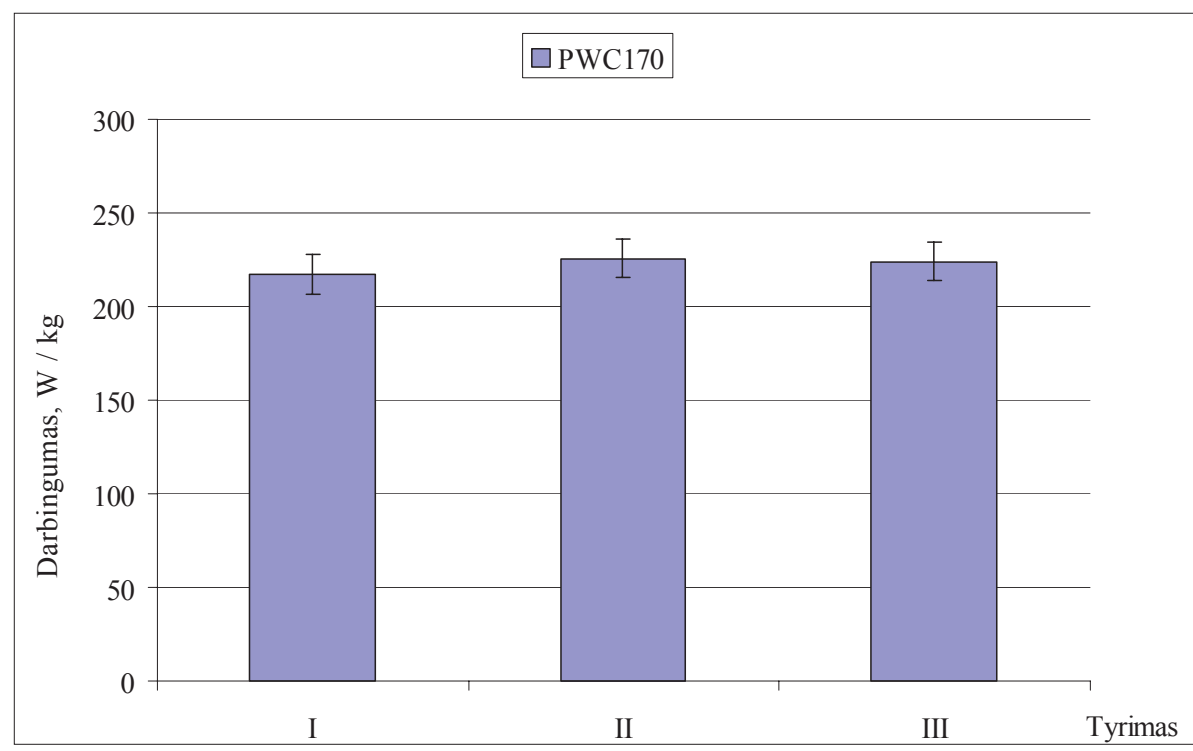

4 pav. Maisto papildo Maca booster poveikis sportininkų anaerobiniam glikolitiniam pajègumui

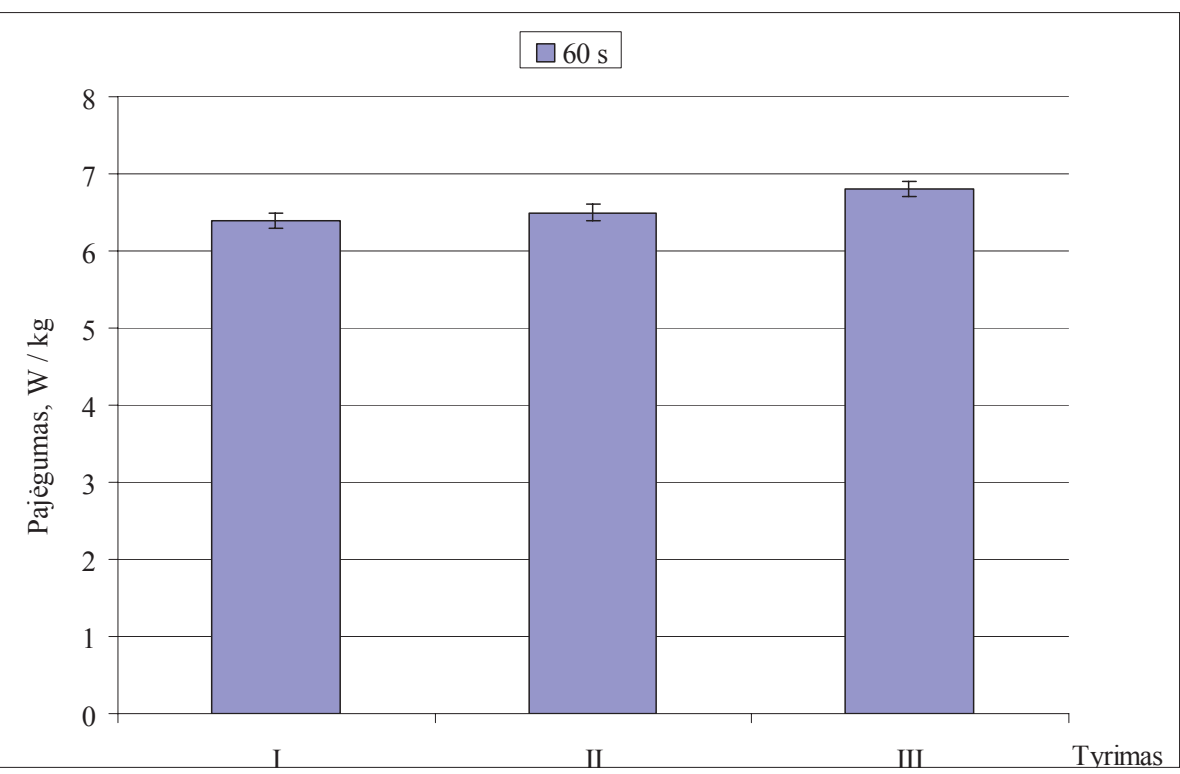

5 pav. Maisto papildo Maca booster poveikis sportininkų fiziniam darbingumui ( $\mathrm{PWC}_{170}$ )

\section{REZULTATŲ APTARIMAS}

Analizuojant atskirus diagnostinius sportininkų fizinio išsivystymo rodiklius matyti, kad sportininkų kūno mase per tiriamaji laikotarpi kito labai mažai. Šio rodiklio procentinè sklaida didelè, viršija $10 \%$. Raumenų masè turèjo tendenciją didèti, tačiau per 20 dienų laikotarpi šie pokyčiai buvo statistiškai nepatikimi.

Taigi apibendrinant galima teigti, kad 20 dienu trunkantis maisto papildo Maca booster vartojimas po 5 kapsules per dieną fizinio išsivystymo rodiklių beveik nepaveikè.

Tyrimas parodé, kad 20 dienų trukmès maisto papildo Maca booster vartojimas veikia sportininku anaerobinio alaktatinio raumenu galingumo rodiklius atliekant $2-3$ ir $10 \mathrm{~s}$ trukmès darbac, kai raumenu mechaninès energijos gamyboje vyrauja adenozintrifosfato (ATF) resintezè iš kretinfosfato (KF). Toks energijos gamybos būdas vyrauja žaidèjų organizme, kai greitejimai trunka nuo 2 iki $10 \mathrm{~s}$, taip pat ir kitų šakų sportininkų, kurių veikla trunka $2-10 \mathrm{~s}$ ir reikalauja maksimalių pastangu.

Lyginant I ir III tyrimo AGP rodiklių vidurkius, nustatytas statistiškai patikimas skirtumas. Per tiriamaji laikotarpi absoliuti AGP reikšmé padidèjo nuo 494,8 $\pm 12,3$ iki 530,1 $\pm 11,0 \mathrm{~W}(\mathrm{p}<0,05)$. Santykinis galingumas statistiškai patikimai padidèjo nuo $6,4 \pm 0,1$ iki $6,8 \pm 0,1 \mathrm{~W} / \mathrm{kg}(\mathrm{p}<0,05)$. Glikolitinių reakcijų suaktyvejjimą rodo laktato koncentracijos kraujyje reikšmingas padidejjimas. Per tiriamaji laikotarpi šis rodiklis didejjo nuo 13,6 $\pm 0,5$ iki 15,5 $\pm 0,6 \mathrm{mmol} / 1$, skirtumas $(1,9 \mathrm{mmol} / \mathrm{l}) \mathrm{yra}$ statistiškai patikimas $(\mathrm{p}<0,01)$. 


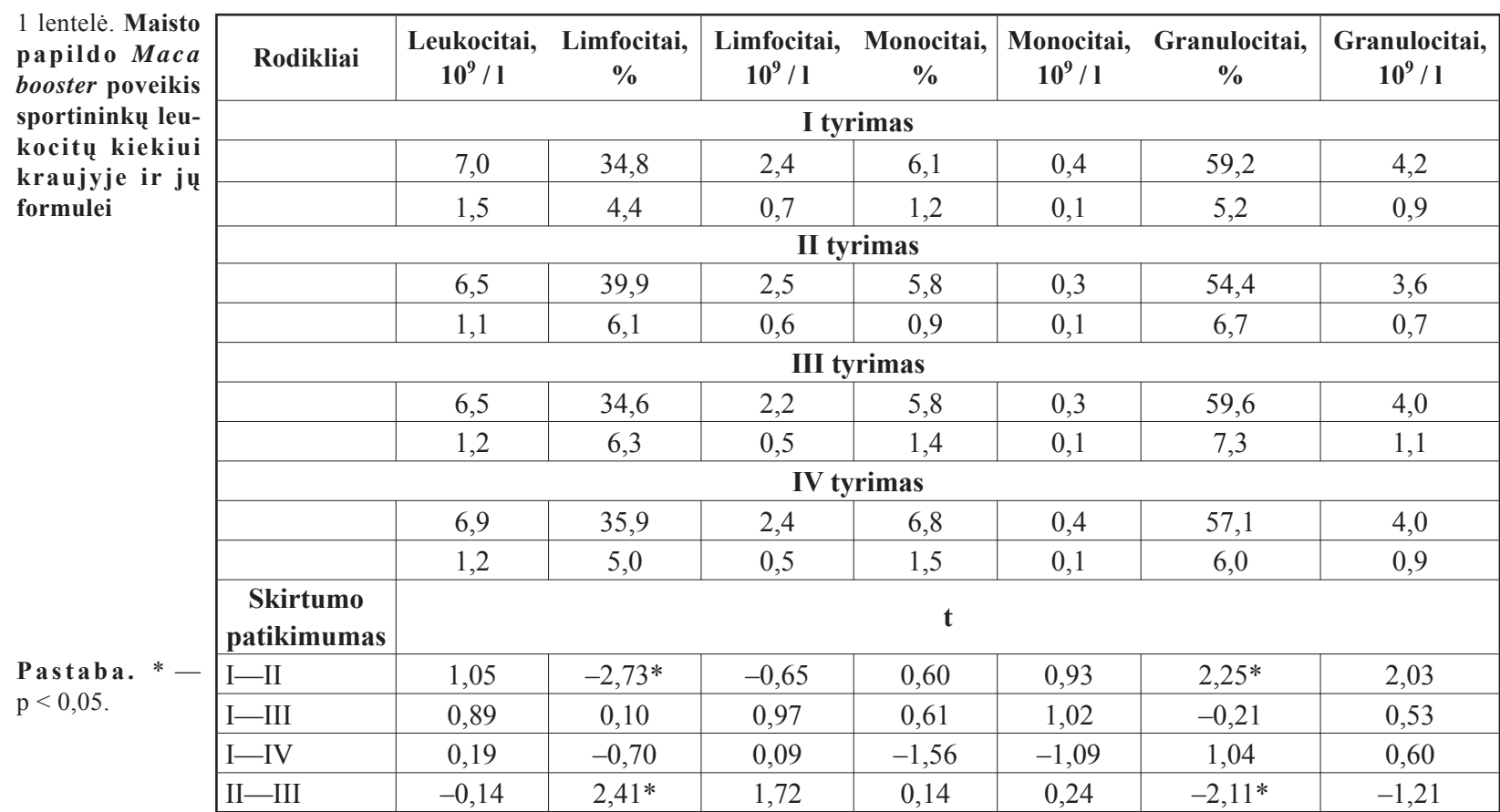

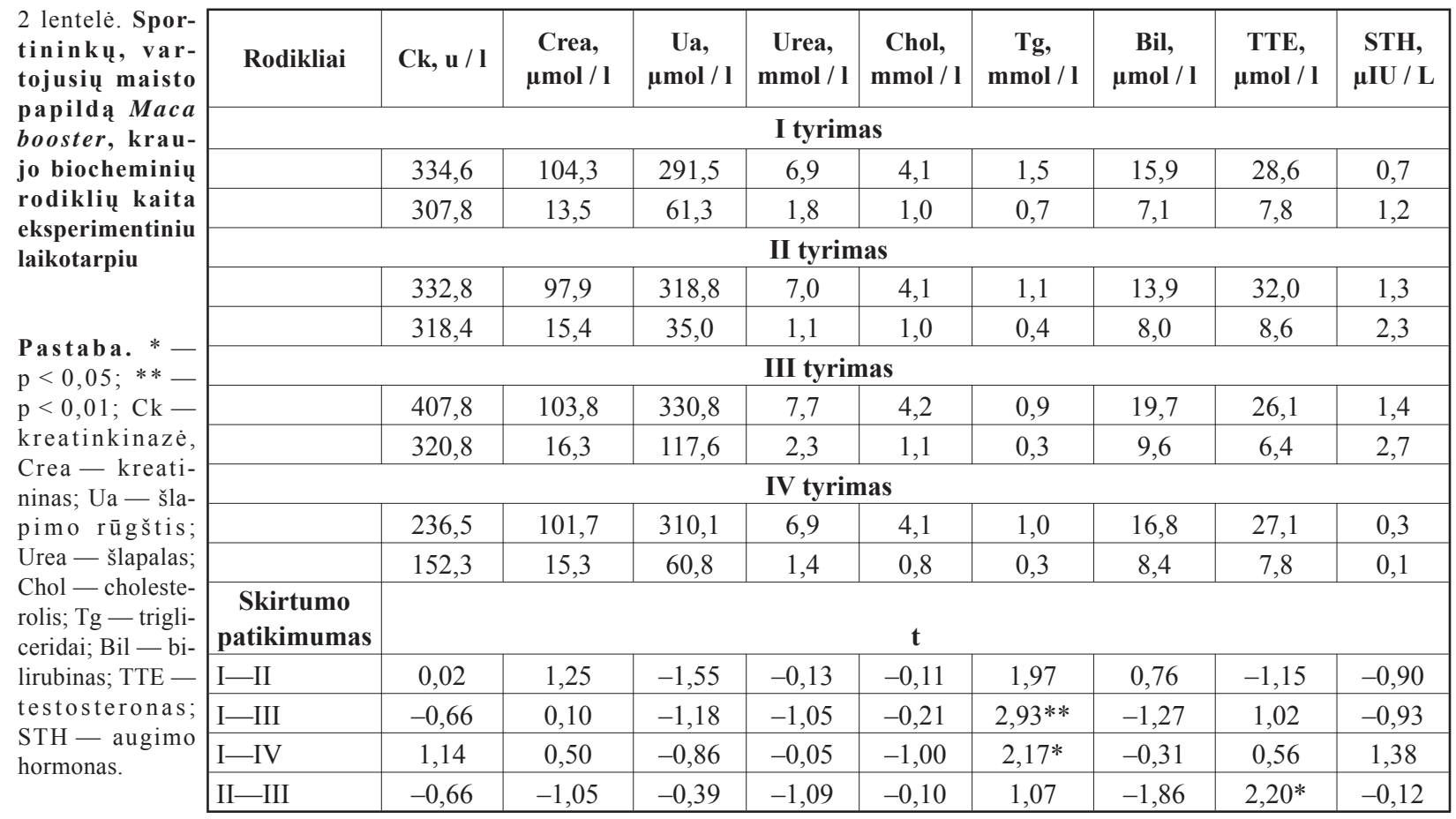

Apibendrinant tyrimų rezultatus galima teigti, kad 20 dienų vartojant maisto papildą Maca booster padidejo anaerobinis glikolitinis pajègumas, kuris išryškejjo po trijų savaičių baigus vartoti maisto papildą. Tai turi teorinę ir praktinę reikšmę tų šakų sportininkams, kurių varžybinè veikla vyksta anaerobinèje glikolitinejje energijos gamybos zonoje, kai darbas trunka nuo 40 iki 120 s. Ilgiau dirbant pradeda vyrauti aerobinès reakcijos, tačiau glikolitinių reakcijų indèlis išlieka reikšmingas, nors darbui ilgejjant procentinè jos reikšmė vis mažèja.

Taigi tyrimas parodé, kad 20 dienų trukęs maisto papildo Maca booster vartojimas teigiamai veikia sportininkų fizini darbingumą. $\mathrm{PWC}_{170}$ rodikliai turi aiškią tendenciją gerèti, tačiau statistiškai šie pokyčiai nèra patikimi, kadangi tiriamasis kontingentas buvo gana skirtingas, rodiklių procentine sklaida didelè, sklaidos plotas sieke $150 \mathrm{~W}$, tarp tiriamujų buvo asmenų, kurių darbo galingumas buvo du kartus didesnis už silpniausio tiriamojo.

Aerobini pajègumą lemia du pagrindiniai veiksniai. Vienas iš jų — raumenų gebejjimas naudojant deguoni resintezuoti ATF ir antras - kraujotakos ir kvèpavimo sistemos funkcinis pajègumas, gebejjimas i dirbančius raumenis pristatyti deguoni, energines ir kitas medžiagas, reikalingas 
aerobinėms reakcijoms vykti. Atliktas tyrimas parodè, kad maisto papildo Maca booster vartojimas nelabai padidino tiriamujų aerobini pajègumą.

Statistiškai reikšmingai sumažèjęs eritrocitų nusėdimo greitis ir limfocitu kiekio bei procentinio rodiklio padidejjimas po 10 dienų maisto papildo vartojimo parodè, kad jis sukèlè limfocitu suaktyvejjimą ir teigiamus leukogramos poslinkius. Limfocitai - tai ne tik ląstelinio ir humoralinio imunologinio atsako lassteliniai komponentai, bet ir įvairių kraujo kamieninių ląstelių grupè, iš kurių gali vystytis kitos kraujo ląstelès (Zaleskis, 2002). Galima teigti, kad maisto papildas Maca booster jau po 10 dienų vartojimo po 5 kapsules per dieną teigiamai veikia sportininkų organizme vykstančias imunines reakcijas.

Statistiškai reikšmingai mažejanti trigliceridų koncentracija, esant pastoviam cholesterolio lygiui sportininkų kraujyje, parode teigiamą šio maisto papildo poveiki lipidų apykaitai organizme.

Atliktas tyrimas rodo, kad pradejus vartoti Maca booster per pirmąsias 10 dienų buvo paskatintas testosterono išsiskyrimas ir padidejo jo koncentracija kraujyje, tačiau toliau vartojant tokią pačią dozę testosterono koncentracija kraujyje vèl sumažèjo. Literatūroje yra nuorodų, kad vartojant Maca booster testosterono kiekis kraujyje nedidèja (Gonzales et al., 2001, 2002, 2003).

Augimo hormono (STH) koncentracija svyravo dideliu diapazonu. I tyrimo metu vieno sportininko, II ir III tyrimų metu trijų sportininkų STH koncentracija kraujyje 2-3 kartus viršijo normą. Visų kitų tiriamujų augimo hormono koncentracija kraujyje eksperimento metu buvo 10 ir daugiau kartų mažesnè už normą. Dèl didelès rodiklių sklaidos nėra galimybės spręsti, ar maisto papildo vartojimas pakeite augimo hormono koncentracija sportininkų kraujyje.

\section{IŠVADOS}

1. 20 dienų trukęs maisto papildo Maca booster vartojimas teigiamai veikia sportininku fizini pajègumą ìvairiose energijos gamybos zonose. Vienkartinio raumenų susitraukimo galingumo absoliutūs ir santykiniai rodikliai turèjo tendenciją didèti, tačiau dèl didelès rodikliu sklaidos statistiškai patikimo padidejimo nenustatyta. Anaerobinis alakatatinis raumenu galingumas didejo taip pat statistiškai patikimai.

2. Anaerobinis glikolitinis pajègumas didejo statistiškai patikimai (tiek absoliučios, tiek santykinès reikšmès). Glikolitinių reakcijų aktyvumas taip pat padidejo.

3. Maisto papildo Maca booster vartojimas teigiamai veikia kraujotakos ir kvejpavimo sistemos funkcini pajègumą. Dauguma šios sistemos rodiklių didèjo statistiškai patikimai.

4. Statistiškai reikšmingai sumažejęs eritrocitų nusèdimo greitis ir padidejęs limfocitų kiekis bei poslinkiai leukocitu formuleje jau po 10 dienu Maca booster vartojimo rodo, kad šis maisto papildas teigiamai veikia sportininkų organizme vykstančias imunines reakcijas.

5. Hormonu tyrimai sportininkų kraujyje parodé, kad testosterono koncentracija po 10 dienu papildo vartojimo turèjo tendenciją didèti, bet neviršijo viršutinių normos ribu, o toliau per eksperimentini laikotarpi šio hormono koncentracija kraujyje išliko normali.

\section{LITERATŪRA}

Bosco, C., Viitasalo, J. T., Komi, P. V., Luchtanen, P. (1982). Combined effect of elastic energy and mioelectrical potentiation during stretch short termini cycle exercise. Acta Physiologica Scandinavica, 114, 557-565.

Brinckmann, J., Smith, E. (2004). Maca culture of the Junin Plateau. Journal of Alternative and Complementary Medicine, 10 (3), 426-430.

Eurofitas: fizinio pajegumo testai ir metodika. (1993). Parengè V. Volbokienè. Vilnius.

Hernandez, B., Leon, J. (1994). Maca. In Neglected Crops: 1492 from a Different Perspective. Rome: Food acid Agriculture Organization (FAO) of the United Nations (UN).

Gonzales, G., Cordova, A., Gonzales, C. et al. (2001). Lepidium meyneii (Maca) improved semen parameters in adult men. Asian Journal of Andrology, 3, 301-303.
Gonzales, G., Cordova, A., Vega, K. et al. (2003). Effect of Lepidium meyenii (Maca), a root with aphrodisiac and fertility-enhancing properties, on serum reproductive hormone levels in adult healthy men. Journal of Endocrinology, 176, 163-168.

Gonzales, G., Cordova, A., Vega, K. et al. (2002). Effect of Lepidium meyenii (Maca) on sexual desire and its absent relationship with serum testosterone levels in adult healthy men. Andrology, 34, 367-372.

Margaria, R., Aghemo, P., Rovelli, E. (1966). Measurement of muscular power (anaerobic) in man. Journal of Applied Physiology, 21, 1662-1664.

Norton, K., Wittingham, N., Carter, L., Kerr, D., Gore, C. (1996). Measurement techniques in anthropometry. In K. Norton, T. Olds, Antropometrica. Sidney. P. 25-75. 
Shugarman, A. E. (2002). Energy pills that work (and don't). Men's Fitness, 18 (3), 44-47.

Szögy, A., Cherebetin, G. (1979) Minuten test auf dem farradergometer zur bestimung der anaeroben capacitat. European Journal of Applied Physiology, 33, 171-176.
Zaleskis, G. (2002). Pagrindiniu laboratoriniu tyrimu žinynas. Vilnius: Vaistų žinios.

Zuniga, L., Flores, D. (2003). Maca (monograph). Lima, Peru: Latin Pharma Expo. P. 8-11.

\title{
EFFECTS OF MACA BOOSTER FOOD SUPPLEMENT ON ATHLETES' BODILY ADAPTATION TO PHYSICAL LOADS
}

\author{
Kazys Milašius, Rūta Dadelienė, Marija Pečiukonienė, Juozas Skernevičius \\ Vilnius Pedagogical University, Vilnius, Lithuania
}

\begin{abstract}
The Maca Booster food supplement (Almondi, Germany), is gaining popularity among athletes. Its basic component is the natural plant Lepidium meyenii (Maca). In folk medicine, maca is used to relieve fatigue, to improve metabolism, immune state and endurance, to strengthen the cardiovascular system. However, these applications lack scientific substantiation. The aim of the present work was to elucidate the effects of the Maca Booster food supplement on athletes' physical capacity and the morphological and biochemical composition of blood.

The study cohort involved 18 athletes aged 20-22 years. They took five capsules of Maca Booster per day. One capsule contained $800 \mathrm{mg}$ of dry maca root powder. The athletes were examined before Maca Booster supplementation, after 10 and 20 days of taking the supplement, and 20 days after its termination.

We examined: single muscular contraction power (SMCP), anaerobic alactic muscular power (AAMP), anaerobic glycolytic capacity (AGC), and aerobic capacity. Vein blood samples were taken for morphological, biochemical and hormonal analyses.

Over the study period, the absolute SMCP increased from $1997.2 \pm 111.1$ to $2137.5 \pm 107.7 \mathrm{~W}$ and the relative SMCP from $25.9 \pm 1.2$ to $27.4 \pm 1.3 \mathrm{~W} / \mathrm{kg}(\mathrm{p}<0.05)$. The relative AAMP index increased from $16.3 \pm 0.3$ to $17.3 \pm 0.4 \mathrm{~W} / \mathrm{kg}(\mathrm{p}<0.05)$. Working capacity under a $10 \mathrm{~s}$ stress load increased from $18.3 \pm 0.5$ to $20.3 \pm 0.5 \mathrm{~W} / \mathrm{kg}(\mathrm{p}<0.05)$. The AGC index increased from $494.8 \pm 12.3 \mathrm{~W}$ to $530.1 \pm 11.0 \mathrm{~W}$ $(\mathrm{p}<0.05)$. Blood lactate level increased from $13.6 \pm 0.5$ to $15.5 \pm 0.6 \mathrm{mmol} / 1(\mathrm{p}<0.01)$. After 20 days of Maca Booster supplementation, $\mathrm{PWC}_{170}$ increased by $8.8 \mathrm{~W}(\mathrm{p}<0.05)$ on average.

During 10 days of the study period the lymphocyte percentage increased from 34.8 to $39.9 \%$, erythrocyte sedimentation rate became significantly lower. Changes in blood creatinekinase, creatinine, uric acid and urea levels showed that its supplementation may potentially increase bodily physical abilities.

As soon as after 10 days of Maca Booster supplementation, a testosterone level increase from $28.6 \pm 1.9$ to $31.9 \pm 2.2 \mu \mathrm{mol} / 1(\mathrm{p}<0.05)$ was noted. This fact indicates that Maca Booster supplementation first enhanced testosterone formation and its blood level increased, however, later the same dose caused a decrease in testosterone level.

Thus, our study has shown a positive effect of Maca Booster supplementation of athletes' physical capacity in various energy production zones and in their immune state.
\end{abstract}

Keywords: food supplements, physical development, physical abilities, functional capacity.

Gauta 2008 m. spalio 7 d.

Received on October 7, 2008

Priimta 2008 m. gruodžio 9 d.

Accepted on December 9, 2008
Kazys Milašius

Vilniaus pedagoginis universitetas

(Vilnius Pedagogical University)

Studentų g. 39, LT-08106 Vilnius

Lietuva (Lithuania)

Tel +370 5 2751748; +37052734858

E-mail kazys.milasius@vpu.lt 